International Journal of Current Advanced Research

ISSN: O: 2319-6475, ISSN: P: 2319 - 6505, Impact Factor: SJIF: 5.995

Available Online at www.journalijcar.org

Volume 6; Issue 4; April 2017; Page No. 3293-3294

DOI: http://dx.doi.org/10.24327/ijcar.2017.3294.0252

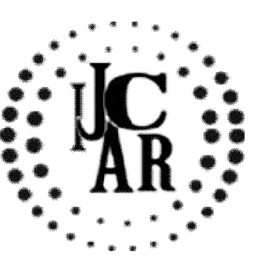

Research Article

\title{
EFFECTS OF AERATED SOFT DRINKS ON THE pH LEVELS IN THE ORAL CAVITY
}

\author{
Sai Sandhya.T and Vishnu priya
}

Saveetha Dental College, Chennai, Tamil Nadu, India

\begin{tabular}{l}
\hline A R T I C L E I N F O \\
\hline Article History: \\
Received $18^{\text {th }}$ January, 2017 \\
Received in revised form $19^{\text {th }}$ February, 2017 \\
Accepted $22^{\text {nd }}$ March, 2017 \\
Published online $28^{\text {th }}$ April, 2017 \\
\hline
\end{tabular}

Key words:

Ph Levels, Oral Cavity

\begin{abstract}
A B S T T R A C T
Aim: To find the effects of aerated drinks on the $\mathrm{pH}$ levels in the oral cavity.

Objective: The objective of the present study is to find the effects of $\mathrm{pH}$ levels after consuming aerated soft drinks.

Background: Maintaining a good $\mathrm{pH}$ balance in the mouth allows a healthy balance of good and bad bacteria.Certain foods such as sugary beverages, snacks and some grains increase the acidity in the mouth.The $\mathrm{pH}$ of mouth can change dramatically with the types of food we eat.The saliva can help neutralise the acid, but eating acidic foods can increase the acidity of the saliva.
\end{abstract}

Copyright $(2017$ Sai Sandhya.T and Vishnu priya. This is an open access article distributed under the Creative Commons Attribution License, which permits unrestricted use, distribution, and reproduction in any medium, provided the original work is properly cited.

\section{INTRODUCTION}

Diet is a major ateiological factor for dental caries and enamel erosion (1). This study was undertaken with the aim of assessing the effects of aerated soft drinks on salivary $\mathrm{pH}$ among adults (2). It is well established that a good diet is essential for the development and maintenance of healthy teeth (3). Saliva plays an important role in maintaining the integrity of teeth by the way of its buffering action and controlling the demineralisation and promoting remineralisation occurring continuously at the enamel surface (4). The normal $\mathrm{pH}$ of saliva is 6.7 to 7.4 but as bacteria breakdown carbohydrates, they release lactic acid, butryic acid and aspartic acid which bring down the $\mathrm{pH}$ of saliva.(5) Fall in salivary $\mathrm{pH}$ after any dietary intake is a crucial parameter of oral health.(6) When the $\mathrm{pH}$ level in mouth goes below 5.5, the acids begin to break down the enamel on teeth.(7) The longer the teeth are exposed to a low salivary $\mathrm{pH}$, the more likely the development of dental caries is.

\section{MATERIALS AND METHODS}

Thirty healthy volunteers were included in the study. The volunteers were between 18-26 years old and free from acute or chronic diseases of general systems or oral cavities. Furthermore they did not have any kind of oral addictions in their past history, such as smoking, alcohol or snuff consumption. One aerated drink is selected for the study to evaluate their influence on human salivary $\mathrm{pH}$. Before consumption of aerated drinks, saliva was collected under room temperature.

*Corresponding author: Sai Sandhya.T

Saveetha dental college, Chennai, Tamil Nadu, India into a test tube through a glass funnel. The participants were then asked to drink $200 \mathrm{ml}$ of soft drinks. After 10-15 minutes of consumption of soft drinks, the saliva was collected and the $\mathrm{pH}$ values of each saliva sample was analysed statistically.

\section{RESULTS AND DISCUSSION}

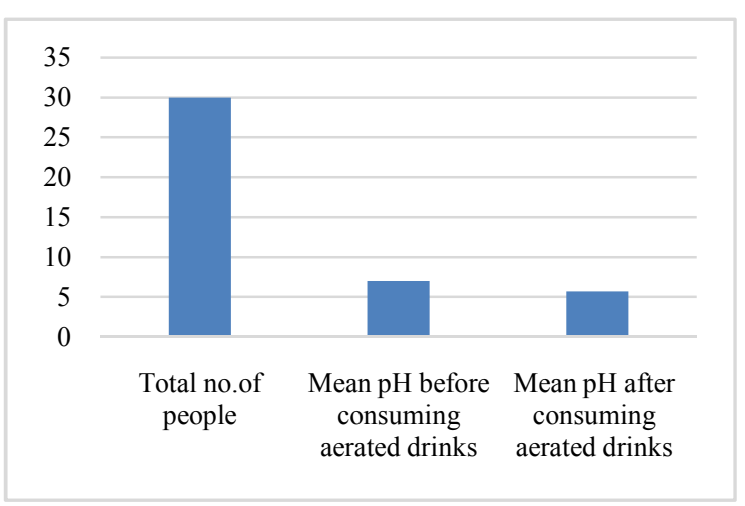

It has been observed that the $\mathrm{pH}$ is same for all participants. The mean $\mathrm{pH}$ before consuming aerated drinks is 7 . The mean $\mathrm{pH}$ after consuming aerated drinks is 5.7 that shows a decline in salivary $\mathrm{pH}$ after consuming aerated drinks.If the time interval is being extended it would bring about a further decline in salivary $\mathrm{pH}$.

\section{CONCLUSION}

The present study clearly indicates that there is a decline in salivary $\mathrm{pH}$ after the consumption of soft drinks. The aerated drinks contain substantial quantities of sugar and acidity content that brings down the $\mathrm{pH}$ level of saliva which is harmful. Therefore it is important to avoid frequent 
consumption of these aerated drinks to reduce the risk for dental caries.

\section{References}

1. Effect of various sugary beverages on salivary $\mathrm{pH}$, among adults. R Hans, S Thomas, B Garla, M K Hans scientifica.

2. Effect of commonly consumed sugar containing and sugar free fruit drinks on the hydrogen ion modulation of human dental plague. N Mahajan, B Kotwal, V Sachdev, Journal of Indian.

3. Influence of soft drinks on salivary pH.Y.N Mojaver, $\mathrm{N}$ Javidi, K Manshaee, Chinese journal of dental..2008 cndent.com
4. Effect on salivary $\mathrm{pH}$ value after consumption of aerated drinks. An in Vito study. Univ Res J Dent 2016; Bhure S Musani, Surveshe.

5. Sour sweets and acidic beverage consumption are risk indicators for dental erosions.

6. J B Soviet, R Skudutyte, Rysstad, A B Jveit, L Sandvik,.. caries..2015-karger.com

7. Association between soft drink consumption, oral health and some lifestyle factors in Swedish adolescents. A Hasselkvist, A Johansson.. odontological...2014-Taylor and Francis.

8. Saliva and tongue coating $\mathrm{pH}$ before and after use of mouthwashes and relationship with parameters of halitosis.

9. Sugars and dental caries -American journal of clinical nutrition-American society for nutrition ajcn.nutrition.org

10. The Effect of cheese on the $\mathrm{pH}$ levels in the oral cavity-TopSCHOLAR by M R Hayden..2015.

\section{How to cite this article:}

Sai Sandhya.T and Vishnu priya (2017) ' Effects Of Aerated Soft Drinks On The Ph Levels In The Oral Cavity', International Journal of Current Advanced Research, 06(04), pp. 3293-3294.

DOI: http://dx.doi.org/10.24327/ijcar.2017.3294.0252 